\title{
10-11 CLASSES STUDENTS AND PHYSICAL EDUCATION TEACHERS SUBJECTIVE OPINIONS ABOUT THEIR PHYSICAL EDUCATION LESSONS MODERNITY
}

\author{
E. Maciulevičienè, Edita.Maciuleviciene@lsu.It \\ Lithuanian Sports University, Kaunas, Lithuania
}

\begin{abstract}
Aim. Research aim was to reveal the subjective opinions of Physical Education teachers and students in higher grades on the realities of modern Physical Education classes. Material and Methods. The sample included Physical Education teachers $(\mathrm{n}=33)$ and $10-11$ th grade students $(\mathrm{n}=324)$ who were selected applying the convenience sampling strategy from Kaunas city schools. The research employed a questionnaire by Pate, Corbin \& Pangrazi (1998), and some more questions of interest to the researchers were added. Results. According to the survey data, students' opinions on the given question mostly differed from teachers' notion. However, the statistical analysis of the obtained data suggested that there is a certain tendency which may be considered in Physical Education lesson planning. Conclusions. Physical Education teachers tend to subjectively better assess the modern realities of the Physical Education classes than students. In particular, it refers to the satisfaction of students, diversity of content, modern teacher personality traits and school disciplinary measures for students. However, an observed trend implies the improvement of evaluation criteria corresponding to modern lesson recommendations.
\end{abstract}

Keywords: lesson, Physical Education, teachers.

\section{Introduction}

Intense changes in national education require new students' teaching technologies in Physical Education. Modern general Physical Education program increases students' self-confidence, nurtures the need for physical activity instils reasoned disposition to look for, try, and find a variety of Physical Education activities, and encourages students to be physically active not only during PE lessons at school, free time, but after leaving school [6].

Teachers of today and the future must also teach Physical Education to their students to remain physically active for the rest of their life $[1,7]$. Himberg et al. (2003) offers to give students the choice of all possible sports activities. Students having limited choice of sports lose the need for exercise, they feel that they can choose only a few physical activities, and if none of them appeals to them, the only option left is to be physically inactive. Choices have to focus on the life and health promoting activities [7].

The aforementioned statements reveal the topicality of the analysed problem and enable the formulation of the study aim - to reveal the subjective opinions of Physical Education teachers and students in higher grades of the realities of modern Physical Education classes.

\section{Methods}

Research group included 33 Physical Education teachers (21 women and 12 men) and 324 students from 10-11th grades (168 girls and 156 boys) selected using a convenience sampling strategy from Kaunas city schools. The research employed a questionnaire by Pate et al. (1998), and some more questions of interest to the researchers were added. The questionnaire for teachers included 24 questions, for students 22 questions. The answers revealed the subjective opinions of the research participants about the realities of modern Physical Education classes. The research participants were surveyed in their schools during the classes with the consent of Physical Education teachers and students and with the permission of school administration received in advance. The survey was based on the ethical and legal research principles. All participants were informed about the objectives of the study and the anonymity of the data. Survey data were processed using the program SPSS for Windows 14. Comparing the groups for statistical difference of data, the significance was tested using Student's $(t)$ and the chi-square $\left(\chi^{2}\right)$ criteria. Results were considered statistically significant if the error probability was $p \leq 0.05$ at $95 \%$ reliability. 


\section{Спортивная тренировка}

\section{Results}

According to the survey data, the students and teachers' opinions on the independent work in classes did not coincide $(\mathrm{p}<0.001)$. More than half $(63,6 \%)$ of Physical Education teachers and $25,9 \%$ of students admitted that independent work was trained in lessons; however, 9,1\% of teachers and $21,3 \%$ of students denied that. Physical Education teachers more often stated that they believed that the content of lessons met the needs of the students $(63,6$ and $22,2 \%$ respectively), while $53,7 \%$ of students and $9,1 \%$ of teachers indicated that only sometimes the content of lessons met those needs $(p<0.001)$. It was found that $54,5 \%$ of Physical Education teachers consulted with students while developing annual thematic plans, while a third $(36,1 \%)$ of students indicated that teachers just sometimes wanted to consult about sports activities $(\mathrm{p}<0.05)$. Other students $(44,4 \%)$ and teachers $(36,4 \%)$ indicated that they never discussed about the desired sports activities $(\mathrm{p}<0.05)$.

Analysing the realities of contemporary Physical Education classes, it is important to figure out what was taken into account while assessing students' achievements as seen by the teachers and students. It was observed that in this regard the opinions differed (Table 1).

Physical Education teachers (Table 1) more often than students stated that the assessment was based on sports technical performance, progress in the development of physical skills and activity during lessons (effort, initiative) $(p<0.05)$, but a quarter of students claimed that teachers had never valued their progress in the development of physical skills and activities in the lessons $(\mathrm{p}<0.05)$.

It was noticed that half of the students surveyed $(50,9 \%)$ stated that Physical Education teachers sometimes took care of poorer health or disabled students and ingeniously integrated them into Physical Education classes and nonformal education. Sometimes Physical Education teachers were friendly and creative, and respected their learners considering their desires $(40,7 \%)$, discussing sports, food supplements, nutrition, safe physical activity, sports clubs, and other topics relevant to the learners $(49,1 \%)$. Also teachers sometimes gave their students the opportunity to try sports and find favourite forms of physical activity, searched for physical exercises appropriate for each particular student, and encouraged the students for motivation for daily physical activity (46,3\%). The findings revealed that Physical Education teachers often conducted lessons of movement skills and sports (Figure 1).

Teachers more often than students (Figure 1) indicated that they always or sometimes led healthy lifestyle and non-traditional physical activity classes $(p<0.01)$, and about half of the students said that this never happened $(p<0.01)$. The findings showed that in most cases lessons on sports and movement skills are carried out. Teacher and student opinions did not coincide on this option.

The survey data showed that most teachers preferred traditional disciplinary measures for students which are not recommended in modern classes. Both teachers and students reported that most often the buzzer was used in the classes (90,9 and 92,3\% respectively), students often pointed out that teachers screamed loudly (respectively 39,4 and $55,5 \%, \mathrm{p}<0.01$ ), and teachers often stated that they clapped their hands $(45,5$ and $30,2 \%$ respectively, $\mathrm{p}<0.01$ ).

\section{Discussion}

Modern Physical Education not only promotes the autonomy of the students, but also enco urages teachers to be innovative. Physical education program must be based on standards, but it also must take into account the needs of the students, focus on the development of skills, and emphasize students' understanding of how to become physically active throughout their lives $[1,7]$. In our study, only one-fifth of the students

Table 1

Distribution of assessment criteria for Physical Education teachers and students

\begin{tabular}{|l|c|c|c|c|c|c|}
\hline \multirow{2}{*}{ Variants of responses } & Teachers & Students & Teachers & Students & Teachers & Students \\
\cline { 2 - 7 } & \multicolumn{2}{|c|}{ Always, \% } & \multicolumn{2}{|c|}{ Sometimes, \% } & \multicolumn{2}{c|}{ Never, \% } \\
\hline Physical fitness test results & 54,5 & 43,5 & 18,2 & $32,5^{*}$ & 27,3 & 24,1 \\
\hline Technical performance of sport & 81,8 & $38,6^{*}$ & 18 & $46,3^{*}$ & 0,0 & $19,7^{*}$ \\
\hline $\begin{array}{l}\text { Progress in physical skill } \\
\text { development skill }\end{array}$ & 27,3 & $7,4^{*}$ & 63,6 & $38,6^{*}$ & 9,1 & $54,6^{*}$ \\
\hline Efforts, initiative, activity & 81,8 & $35,2^{*}$ & 9,1 & $38,6^{*}$ & 0,0 & $25,3^{*}$ \\
\hline Attendance of classes & 54,5 & 53,7 & 36,4 & 36,1 & 9,1 & 10,2 \\
\hline
\end{tabular}

$* \mathrm{p}<0.05$, compared to teachers' responses. 


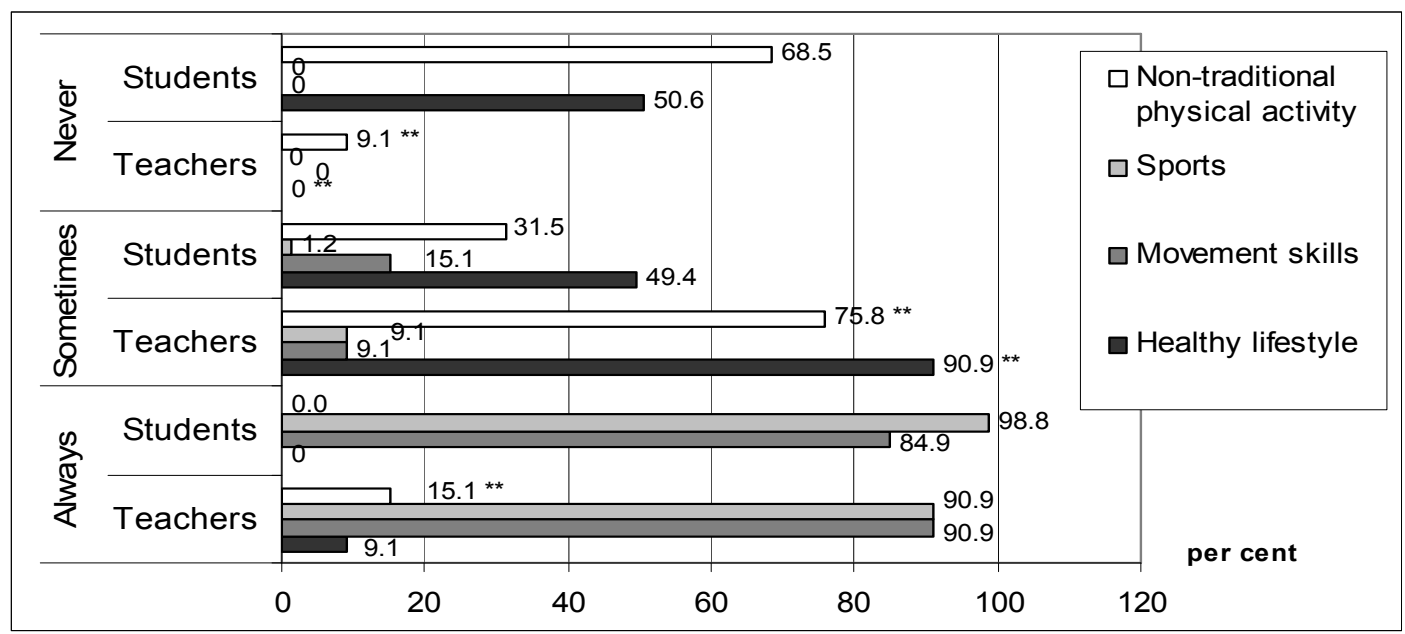

Figure 1. Distribution of frequency data of Physical Education lesson content:

${ }^{* *} p<0.01$ - compared to students' responses

reported that lessons met their needs, which reveals the poor response to model of the modern lessons. This is also confirmed by other research results, where we can see that in most cases Physical Education teachers did not discuss matters with the students what sports activities they would like to have during the classes and did not take into account stundents' needs, which according to Himberg et al. (2003) reduces the need for students to play sports and be physically active at school and after school, which diminishes the main goal of the General Physical Education Programme - to develop students' physical activity for life. The research showed that PE classes still largely dominated by sports and movement skills, and only sometimes they were non-traditional or about healthy lifestyle. Teachers conducted unconventional Physical Education lessons are very important and students are pleased [2].

While assessing students, the General Physical Education Programme proposes to consider the students' physical abilities, to each student's individual characteristics and each student's progress. Our study revealed that teachers paid attention to assessing attendance, but more often they took into account their individual efforts and improvements, which according to Morgan Sproule, \&Kingston (2005), gives all students the opportunity to experience success. Physical Education teachers sometimes have difficulty in assessing students' physical abilities; they lack a uniform system of assessment and evaluation methods as well as specific examples. However, the traditional evaluation which involves the comparison of students' Physical Education results does not meet the personal expectations of students.
The continuous development and use of modern methods enable Physical Education to become an integral part of other subjects, thus covering a harmonious physical and spiritual development of the students, which accompanies them to adulthood [3, 7].

\section{Conclusions}

Physical Education teachers tend to subjectively better assess the modern realities of the Physical Education classes than students. In particular, it refers to the satisfaction of students, diversity of content, modern teacher personality traits and school disciplinary measures for students. However, an observed trend implies the improvement of evaluation criteria corresponding to modern lesson recommendations.

\section{References}

1. Himberg C., Hutchinson G.E., Roussell J.M. Teaching Secondary Physical Education. Preparing Adolescents to be Active for Live. United States: Human Kinetics, 2003.

2. Lykesas G., Tyrovola V. Creativity as an Approach and Teaching Method of Greek Traditional Dance in Secondary Education. Studies in Physical Culture and Tourism, 2009, vol. 16(2), pp. 207-214.

3. Mededovic A., Pljakic B., Mededovic E. Physical Education Improvement in the Process of Modern Organization of Work. Activities in Physical Education and Sport Federation of the Sports Pedagogues of the Republic of Macedonia, 2013, pp. 129-131.

4. Morgan K., Sproule J., Kingston K. Effects of Different Teaching Styles on the Teacher Behaviours that Influence Motivational Climate and Pupils Motivation in Physi- 
cal Education. European Physical Education Review, 2005, vol.11(3), pp.1-27. DOI: 10.1177/1356336X05056651

5. Pate R., Corbin C., Pangrazi B. Physical Activity for Young People. President's Council on Physical Fitness and Sports Research Digest, 1998, vol. 3(3), pp. 1-6.

6. Sandercock G.R.H., Ogunleye A., Voss C.
Screen Time and Physical Activity in Youth: Thief of Time or Lifestyle Choice. Journal of Physical Activity and Helth, 2013, vol. 9(7), pp. 977-984.

7. Shephard R.J., Trudeau F. The Legacy of Physical Education: Influences on Adult Lifestyle. Pediatric Exercise Science, 2000, vol. 12, pp. 34-50.

Received 17 March 2016

УдК 378.172 + 37.011.31-051:796

DOI: 10.14529/hsm160207

\title{
СУБЪЕКТИВНЫЕ МНЕНИЯ О РЕАЛИЯХ СОВРЕМЕННОЙ ФИЗКУЛЬТУРЫ ПРЕПОДАВАТЕЛЕЙ ФИЗКУЛЬТУРЫ И УЧЕНИКОВ
}

\section{Э. Мацюлевичене}

Литовский спортивный университет, г. Каунас, Литва

\begin{abstract}
Цель исследования - изучить субъективное мнение преподавателей физической культуры и школьников старших классов о реалиях современной физической культуры. Материал и методы. В исследовании приняли участие школьные преподаватели физической культуры $(\mathrm{n}=33)$ и учащиеся 10-11 классов $(\mathrm{n}=324)$ школ г. Каунаса, Литва, выбранные случайным образом. Испытуемые прошли анкетирование, основанное на опроснике Pate, Corbin \& Pangrazi (1998), а также включавшее ряд вопросов, сформулированных исследователями. Результаты. По данным анкетирования, мнение студентов и преподавателей по большинству вопросов не совпадало. Однако статистический анализ полученных сведений выявил общую тенденцию, которую рекомендуется учесть преподавателям при планировании занятий по физической культуре. Выводы. Преподаватели физической культуры склонны к более положительной субъективной оценке современных реалий физической культуры, нежели студенты. Такой вывод, в частности, основывается на анализе того, насколько студенты довольны занятиями, а также исходя из разнообразности содержания занятий, личности современного преподавателя физкультуры и принятых школьных нормативах. Однако наблюдаемая тенденция подразумевает улучшение оценочных критериев, на которых могут быть основаны рекомендации по организации современных уроков физической культуры.
\end{abstract}

Ключевые слова: школьники, физическая культура, преподаватели.

Эдита Мацюлевичене, Литовский спортивный университет, г. Каунас, Литва, Edita. Maciuleviciene@1su.1t.

Поступила в редакцию 17 марта 2016 г.

\section{ОБРАЗЕЦ ЦИТИРОВАНИЯ}

Maciulevičienè E. 10-11 classes students and physical education teachers subjective opinions about their physical education lessons modernity / E. Maciulevičienè // Человек. Спорт. Медицина. - 2016. - Т. 16, № 2. C. $67-70$. DOI: $10.14529 / \mathrm{hsm} 160207$

\section{FOR CITATION}

Maciulevičienè E. 10-11 Classes Students and Physical Education Teachers Subjective Opinions about Their Physical Education Lessons Modernity. Human. Sport. Medicine, 2016, vol. 16, no. 2, pp.67-70. DOI: $10.14529 / \mathrm{hsm} 160207$ 